\title{
Kunst en gezondheid
}

\author{
Henriëtte F. Treurniet
}

Published online: 5 June 2018

(C) Bohn Stafleu van Loghum is een imprint van Springer Media B.V., onderdeel van Springer Nature 2018

'Als je gaat zingen met mensen met dementie, dan activeer je het klankgeheugen (...) Eigenlijk masseren mensen zichzelf wakker. Dit is het wetenschappelijke verhaal. Maar wat je ziet is dat mensen meer opengaan. Je ziet ze kijken, focussen. Er komt een glimlach (...) Emoties en spanningen komen los.' En: 'Geneeskunde en kunst hadden ooit een sterke band met elkaar. De kunstenaar was nodig voor de weergave van wat de arts waarnam of ontdekte. In de huidige tijd lijken kunst en geneeskunde twee gescheiden werelden te zijn (...) Terwijl in de kunst de nadrukt lijkt te liggen op een zintuiglijke en subjectieve ervaring, ligt binnen de geneeskunde vooral de nadruk op het objectieve en het formele.'

Het zijn twee citaten uit de artikelen die $u$ in dit Spectrum aantreft. Wat kan kunst betekenen voor gezondheid? Dat is de vraag die de auteurs, werkzaam in uiteenlopende zorgsectoren, zich hebben gesteld. En het antwoord wijst, door de oogharen gezien, in één richting: kunst in de zorg doet ertoe. Het maakt studenten geneeskunde alerter; ze verruimen hun blik en durven onzekerheid te omarmen. Het brengt de dialoog tussen arts en patiënten op gang; zoals een kunstenaar zich voortdurende moet aanpassen aan patronen of eigenschappen van de materie, zo past de arts zich aan aan wat de patiënt nodig heeft. En muziek en dans komen tegemoet aan een diep menselijke behoefte aan nabijheid en aanraking, zo is gebleken in de zorg voor mensen met dementie.

Als kunst zoveel waarde toevoegt aan de curatieve en langdurige zorg, zou dat ook wel eens het geval kunnen zijn voor preventie en publieke gezondheid, en voor de gezondheid van een ieder van ons. Díe vraag blijft hier onbeantwoord. Maar het zou me niet verbazen als $\mathrm{u}$ na het lezen van dit Spectrum toch weer eens de museumkaart pakt, een dansvoorstelling bezoekt of zelf met uw kunsttalenten aan de slag gaat. En dat lijkt me een gezonde zaak. 